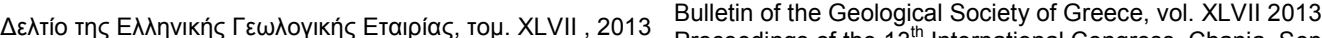
Proceedings of the $13^{\text {th }}$ International Congress, Chania, Sept.

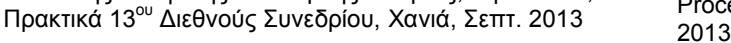

\title{
DEFINITION OF INFERRED FAULTS USING 3D GEOLOGICAL MODELING TECHNIQUES: A CASE STUDY IN TYMPAKI BASIN IN CRETE, GREECE
} \author{
Panagopoulos G.
, Giannakakos E. ${ }^{1}$, Manoutsoglou E.
Soupios P..$^{3}$ and Vafidis A. \\ ${ }^{I}$ Technical University of Crete, Dept. of Mineral Resources Engineering, Research Unit of \\ Geology,Chania,Greece,gpanagopoulos@isc.tuc.gr,emanout@mred.tuc.gr. \\ ${ }^{2}$ Technical University of Crete, Dept. of Mineral Resources Engineering, Laboratory of Applied \\ Geology, Chania, Greece, stiakaki@mred.tuc.gr. \\ ${ }^{3}$ Department of Natural Resources \& Environment, Technological Educational Institute of Crete, \\ soupios@chania.teicrete.gr \\ ${ }^{4}$ Technical University of Crete, Dept. of Mineral Resources Engineering, Laboratory of Applied \\ Geophysics, Chania, Greece,vafidis@mred.tuc.gr.
}

\begin{abstract}
The purpose of this paper is to recognize inferred faults in Tympaki basin (Crete island) which cannot be observed on the surface, as the area is covered by recent deposits. The identification of the faults is crucial for the study of the sea-water intrusion in Tympaki basin that has been observed during the last years.

$3 D$ geological modelling techniques were used for reaching the aforementioned goal. The data used include the digital elevation model (DEM) of the area, the boundary surface between geologic formations and the litho - stratigraphic logs of thirty nine (39) wells. Initially a 3D stratigraphic model was set-up depicting the spatial extension of Plio-Quaternary and Neogene deposits. Next, with emphasis on the litho - stratigraphic logs of the wells, the boundary between the geological formations was defined in a $3 D$ space.

The regional unconformity between the Plio-Quaternary and Neogene formations is possibly the result of tectonic activity of inferred faults. The traces of the inferred faults were drawn and they were compared with the faults suggested by previous studies.
\end{abstract}

Key words: geological structure, $3 D$ geological modelling technique, inferred faults.

\section{Пєрí $\eta \psi \eta$}

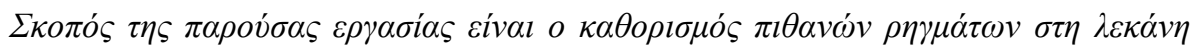

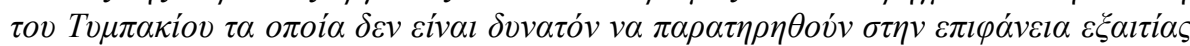

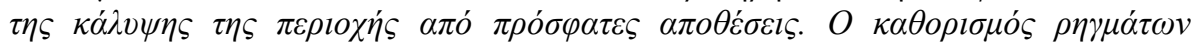

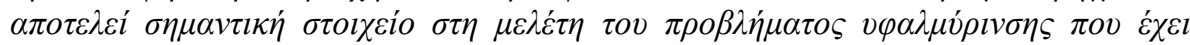

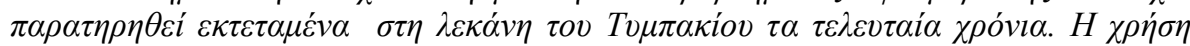

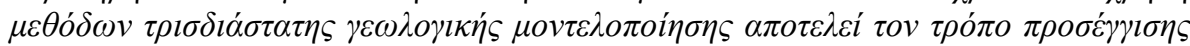

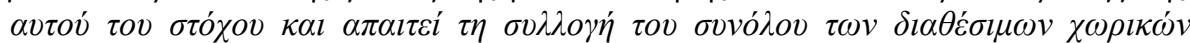

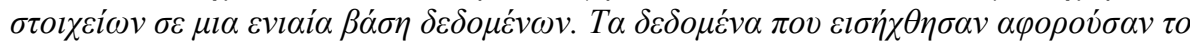

XLVII. No $2-605$ 


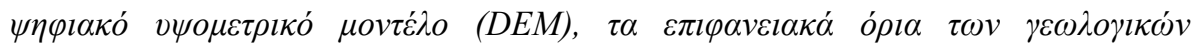

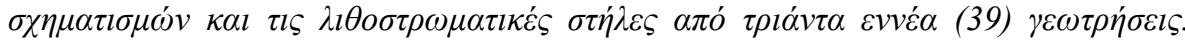

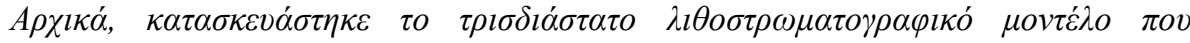

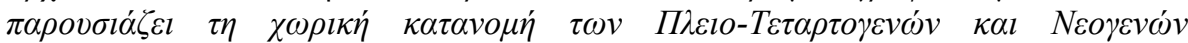

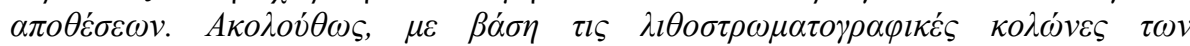

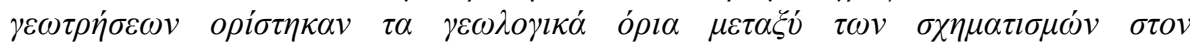

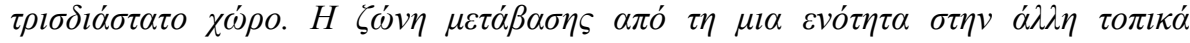

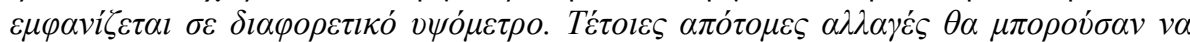

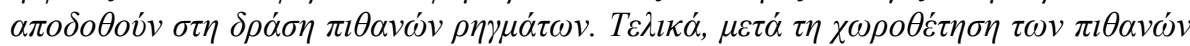

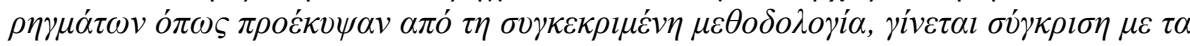

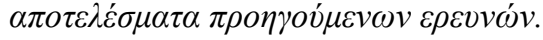

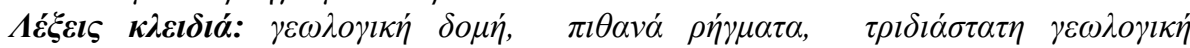
$\mu о \nu \tau \varepsilon \lambda о \pi о i ́ \eta \sigma \eta$.

\section{Introduction}

Crete is a structurally complex area that has been strongly affected by the Alpine orogenic processes in Eastern Mediterranean, due to plate convergence of Eurasian and African plates and the subduction of the Tethyan oceanic crust (Bonneau 1984; Lister et al., 1984; Mountrakis et al., 2006; Ring et al., 2010). Nappe stacking and compression alternate with extension, nappe collapse and exhumation of deep crustal rocks (Bonneau, 1984; Seidel et al., 1982; Kilias et al., 1994, 2002; Jolivet et al., 1996).

The island of Crete is situated in a fore-arc position above the active northward-directed subduction zone of the African plate beneath the Aegean plate (Petereck and Schwarze 2004). Present-day convergence rates between Libya and Crete reach $30 \mathrm{~mm} / \mathrm{yr}$ in a SSW (Oral et al., 1995, Reilinger et al., 1997, McClusky et al., 2000). Given that the movement of Africa towards northward direction is approximately $10 \mathrm{~mm} / \mathrm{a}$, the overall plate convergence rate is approximately 40-45 mm/a. This convergence results to the NE-SW strong convergence compression (perpendicular to the African-Aegean plate boundaries) and to moderate extension to an arcparallel E-W extension field (Petereck and Schwarze, 2004 and references therein).

The highly mountainous landscape in Crete and the deposits of Middle Miocene to early Late Pliocene age, which uplifted up to several hundreds of meters above the present sea-level, suggest a quite recent and rapid uplift. Along the Hellenic arc and south of Crete, the oblique convergence of the two plates explains the existence of fore-arc troughs controlled by strike-slip faults (Peterek and Schwarze, 2004 and references therein).

A large number of surface faults, such as Klima fault, Kardiotissa fault and others, indicate an intense tectonic activity in the region. The present-day surface deformation of south-central Crete is still a matter of debate. Mostly, a multi-directional extension (Duermeijer et al., 1998) has been proposed, based on fault slip data which are however hardly interpreted. Nevertheless, a dominating arc-parallel extension during Late Pliocene to Holocene time is also postulated due to young surface faulting. The existence of sinistral wrenching is evaluated as the main cause of evolution of the isolated Pliocene and younger basins in south-central Crete (Peterek and Schwarze, 2004 and references therein).

Moreover, recent studies (Chatzaras et al 2006; Tortorici et al., 2010; Kokinou et al., 2012; Klein et al., 2013) cast doubts on the duration of extension as a constantly major tectonic regime, suggesting that compression has played a crucial role beyond Middle Miocene. All these different views support the aspect that highly active tectonic setting of Crete affects the integrity and continuity of the stratigraphical units. This led to several fault-bounded blocks which bring in contact different stratigraphic units.

$\underline{\text { XLVII. No } 2-606}$ 
Several projects (FAO, 1969, 1972 \& MEDIS, 2005) have been conducted in Tympaki area during the previous years. The first study performed by FAO (1969). The hydrogeological setting of the whole Messara plain (including Tympaki area) was defined, based on numerous drilling and geophysical data. More recently, in 2005 the MEDIS research project focuses for the first time on the seawater-intrusion phenomenon that had been observed in the Tympaki costal area.

The scope of the present paper is to contribute to the clarification of the tectono-stratigraphical structure of Tympaki basin, especially in the area which is covered by recent deposits, where no surface data exist. Such information will contribute to defining the hydrogeological setting of the basin.

\section{Geological Setting}

Crete consists of a pile of nappes that contain rock units from various geotectonic zones. These rocks belong both to External Hellenides, namely Phyllite (P-Q), Tripolis, Pindos Nappes and to Internal Hellenides, namely Arvi, Miamou, Vatos, Asterrousia Units and ophiolites, all stacked southward on the parautochthonous Permian-Tertiary Plattenkalk Group (Bonneau, 1984). The uplift and exhumation of the basement was accompanied by structural disintegration of the hanging wall, leading to formation of sedimentary basins on top of the nappe pile from Lower to Middle Miocene. Neogene sediments of Crete were subdivided by Meulenkamp (1979) into six stratigraphical groups, namely Prina, Tefelion, Vrysses, Hellenikon, Foinikia and Agia Galini Groups and the undifferentiated Pleistocene. The sedimentary characteristics of Neogene deposits reflect the tectonic regime of the Hellenic fore-arc at the time of their deposition.

The broader area of Tympaki is the westernmost part of Messara basin that is surrounded by Idi Mountains in northwest, Dikti Mountains in the northeastern side and the Asteroussia mountains in the south. Sedimentation in Messara basin started during the Middle Miocene and it resulted in deposition of sequences of conglomerates, cobbles, sands, marls and clays with abrupted lateral and vertical lithological changes.

Tympaki basin is separated from Messara basin by a tectonic horst that is named "Faistos horst" and it is oriented NNE-SSW (Figure 1). Faistos horst is filled with Neogene deposits, which are regarded as aquitard and separates hydrogeologically the Tympaki basin from the eastern part of Messara basin. There is only an approximately $2 \mathrm{~km}$ - wide passage through the horst, on which Geropotamos river flows towards the west.

Tympaki basin exhibits a pronouncedly differentiated relief, with an almost flat south-western domain proximal to the coast, and a north eastern hilly domain proximal to Idi Mountains. The hilly landscape is because of the action of Klima fault to the north and Kardiotissa fault to the east.

The majority of Tympaki basin, especially the south western part, is covered by recent fluviolacustrine and alluvial deposits, while the north western domain is covered by fluvial deposits and alluvial fans (Figure 1). According to previous projects (FAO, 1972; Paritsis, 2005), the borders of the basin are defined by the tectonic contact of the aforementioned deposits with normal faults with the Neogene formations, as it is shown in the geological map of the area (Bonneau et al., 1984 and Bonneau, 1985). Apart from the fault boundaries of Tympaki basin, the same studies suggest the existence of additional normal faults that configure crucially the geometry of Tympaki basin. More specifically, according to the results of MEDIS program (Paritsis, 2005), there are also three additional inferred faults in the area (F1, F2, F3 depicted in Figure 2) which are not shown in the geological map of IGME (Bonneau et al., 1984 and Bonneau, 1985). The claim regarding the existence of these normal faults is based on the litho - stratigraphic logs of deep wells and on hydrogeological data retrieved from FAO project (FAO, 1972). These faults comprise a strike in a mean direction from NNW to SSE (Figure 2). In addition, according to a morphotectonic study in the same basin, conducted by Peterek \& Schwarze (2004), similar faults exist. 


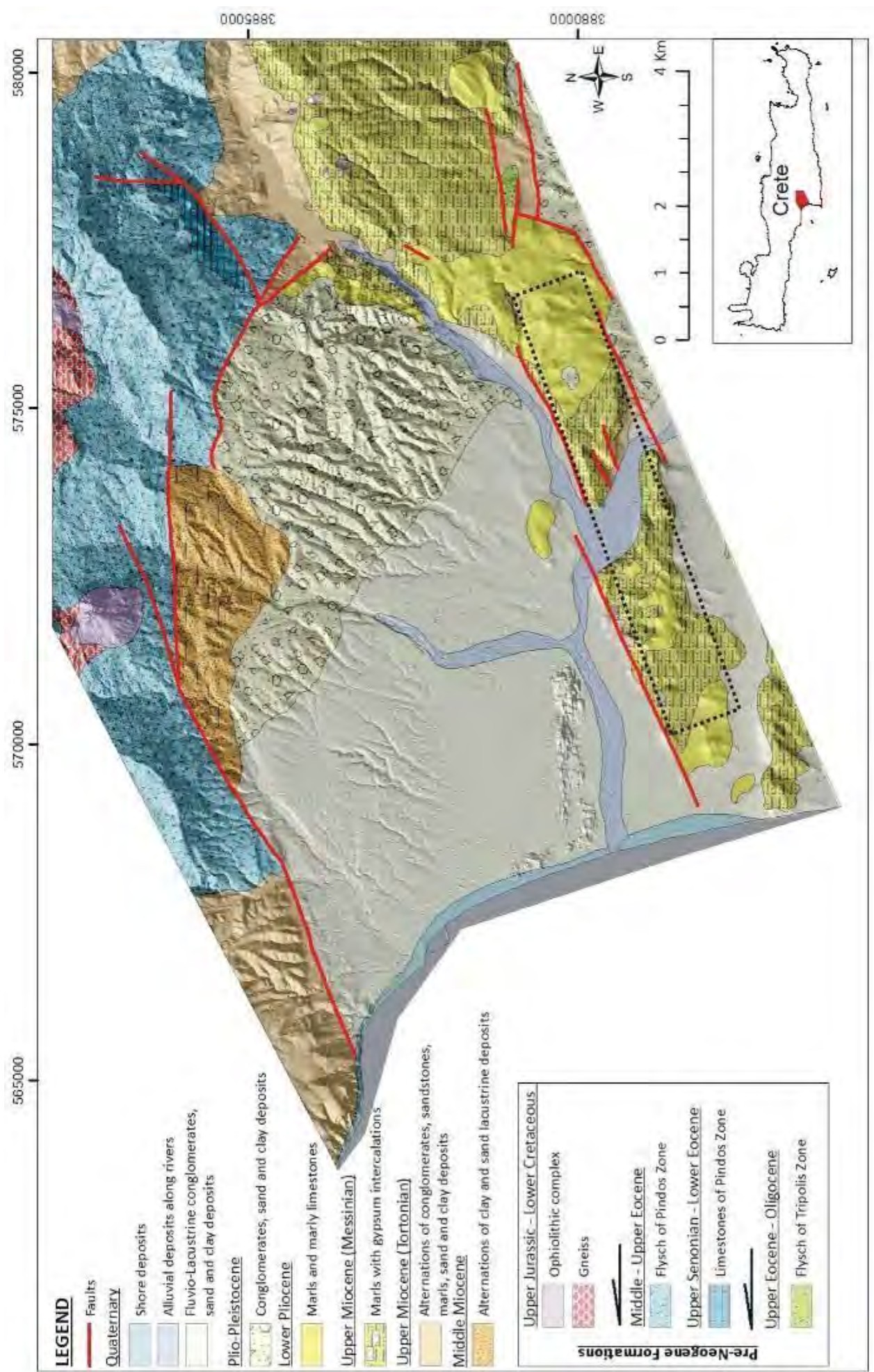

Figure 1 - Geological map of Tympaki area (after Bonneau et al., 1984 and Bonneau, 1985, modified). Dashed line shows the limits of Faistos horst. 


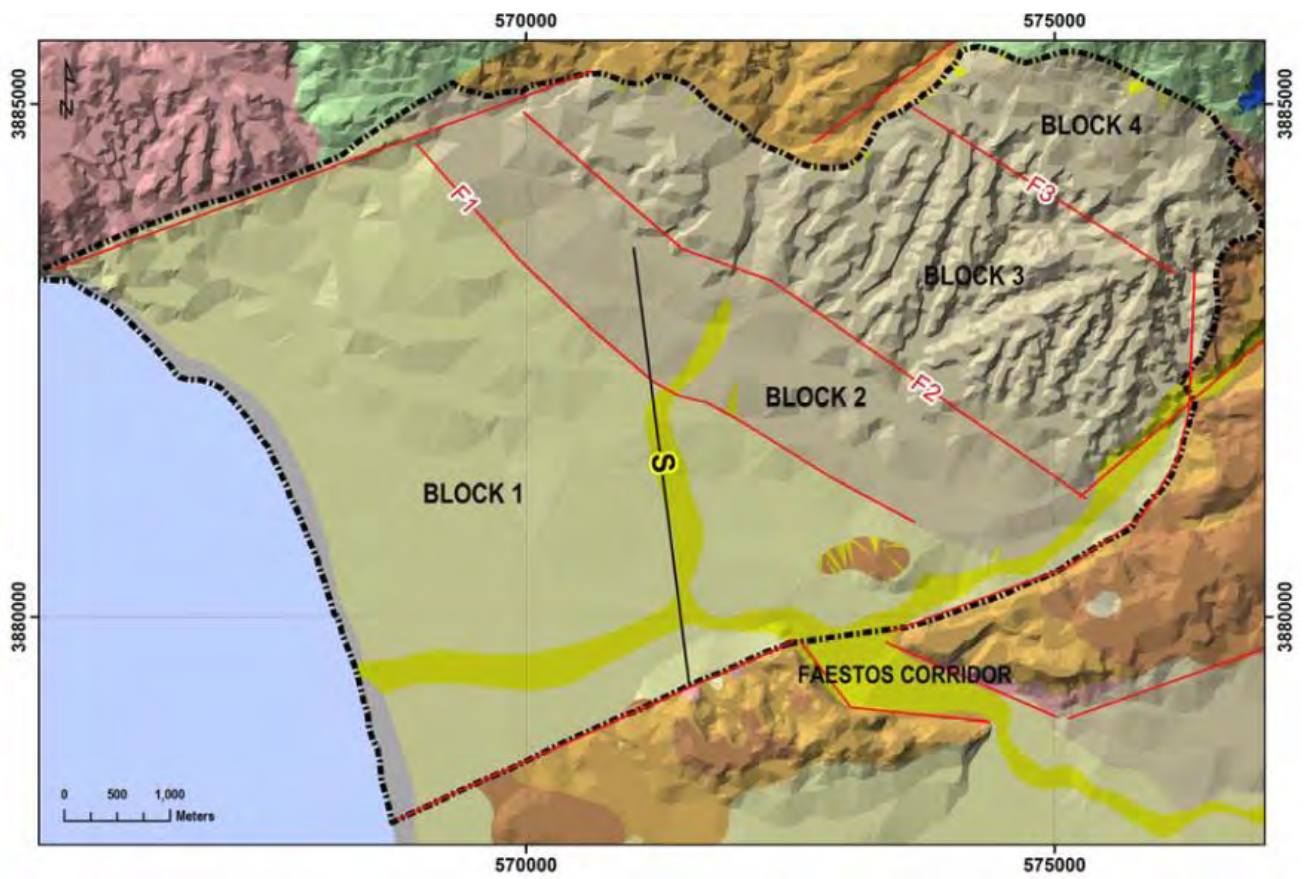

Figure 2 - Geological map of the Tymbaki basin (Paritsis, 2005). Different colours refer to different lithologies based on geological map of IGME (Bonneau et al., 1984 and Bonneau, 1985). The black dash-dot line delimits the basin boundary. F1, F2, F3 are the postulated normal faults dissecting the aquifer.

\section{Methodology}

\subsection{General}

In order to construct the 3D geological model of Tympaki basin, a GIS geological database (ArcGIS) with all the available data was created. Although data integration and cross-correlation of geology can be achieved in two dimensions by the GIS package, it cannot build complex surface or volumes such as geological folding and faulted structures (Kaufmann \& Martin, 2008) in three dimensions. The limited capabilities in handling real 3D data with GIS packages, can be overcome using a specialized 3D geomodeling software.

Based on the above, the GIS database of Tympaki area was imported in the geomodeling software (RockWorks15, RockWare, Inc) and it was integrated by the 3D modelling process. The combined use of both types of software is desirable because it generates more complete and reliable models (Fallara et al., 2006).

The imported data comprises the digital elevation model (DEM) of the area, the surface-geological boundaries and thirty nine (39) well logs. DEM was produced from elevation data (National Cadastre \& Mapping Agency S.A.) acquired from a regular grid with cell dimensions of $5 \mathrm{~m} \times 5 \mathrm{~m}$. In addition, the surface geological data comprise the digitized formation boundaries and the faults lines. Moreover, based on detailed lithological descriptions of the well logs (FAO, 1969; Municipality of Faistos), the geological formations were grouped into 23 lithological units. They were further summarized into two startigraphic units, namely Plio-Quaternary Unit and Neogene Unit (Figure 3). The former consists of clay to pebble deposits and the latter consists mainly of marls and marly limestones. It was assumed that marl formation with thickness over $10 \mathrm{~m}$ could be regarded as a part of the Neogene. 


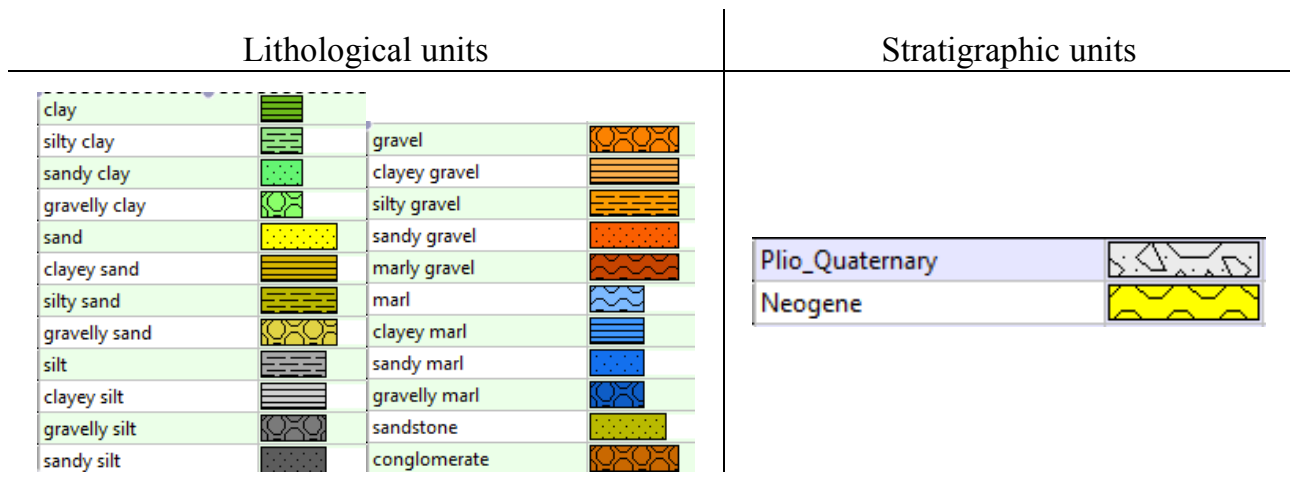

Figure 3 - The litho stratigraphic units loaded in the geomodeling software to define the structural model.

\subsection{Application of 3D Modelling for the Definition of Covered Structural Model.}

In sites covered by recent deposits the recognition of tectonic events is served only by morphotectonic methods, especially by the DEMs. However, there are several cases that none morphotectonic feature can be observed, like an area with flat topography. Tympaki basin is such a case, with small changes in surface elevation mainly in the southwestern part of the basin. The only way to approach the covered geological structure is to gather all the available data and to identify sound changes in the lateral continuity of the strata with reference to the borehole logs.

In the present study thirty nine (39) borehole logs were used to construct the 3D lithostratigraphic model of the area. The maximum depth of the wells reaches at about $350-400 \mathrm{~m}$ mainly for the wells that have been drilled in the hilly part of the area. The spatial data manipulation was made easier by using the 3D modelling software. Based on the lithological descriptions of the borehole logs, the strata were subdivided into two main lithostratigraphic units, namely Plio-Quaternary and Neogene Units (Fig. 3). Twenty five (25) of the boreholes have drilled the Neogene formation near the basin borders, while none of the boreholes have reached the underlying pre-Neogene basement.

The digital 3D model was built by using all the existing data sets and the spatial distribution of the geological bodies was defined so as to be able to locate the upper and lower surface of each geological unit in any part of the basin. Especially, the definition of the surface that bounds the Plio-Quaternary and Neogene Units is crucial because any abrupt alteration in elevation could be able to supply very useful information for the definition of a fault that cannot be observed in the surface (Figure 4). The design of a contour-map for this surface is a quick and easy task, when using 3D geological modelling techniques, and it is really useful for the detection of these abrupt changes in a basin-wide scale, constituting a support tool in the design of a fault.

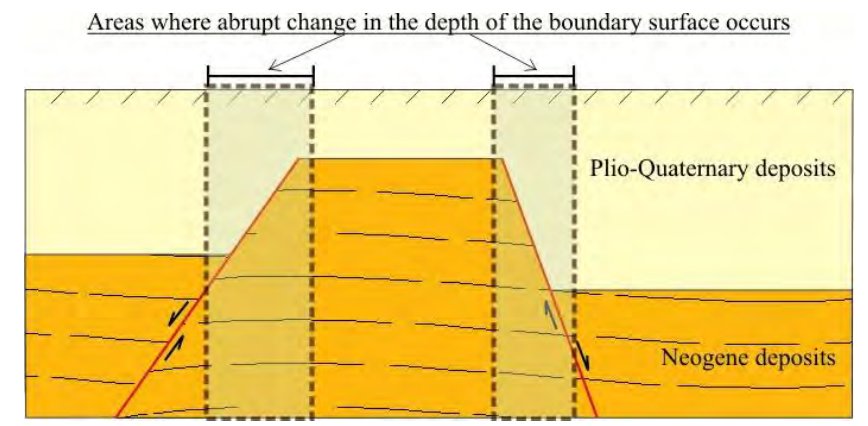

Figure 4 - The concept for identifying areas in the surface where the existence of a fault it is probable. The abrupt change of the boundary surface in depth serves as a guideline.

XLVII. No $2-610$ 
The surface was defined by interpolating the elevation of the lithostratigraphic contact observed in each borehole, with the remaining area between the boreholes. In this case the boreholes are regarded as reference points.

In the present study the used interpolation algorithm is triangulation. The accuracy of the resulting surfaces can be evaluated by cross-validating the model. During this process each of the observed values is regarded as unknown and the algorithm runs every time to calculate a value for it. Then, predicted and observed values are correlated, in order to calculate the correlation coefficient and to conclude regarding the reliability of the results.

Data from 25 out of 39 boreholes were used for cross-validation process, because these wells have reached up to the stratigraphical contact between Plio-Quaternary and the Neogene Units in the area (inside the basin borders).

\section{Results}

The boreholes data have been checked through geological sections and fence diagrams and finally led up a geological 3D model of the studied area (Figure 5). The surface that bounds the Neogene (lower) and Plio-Quaternary (upper) formation was defined reasonably well. The cross-validation showed that only 3 of the 25 predicted values were slightly to strongly different in relation to the real values, while the correlation coefficient estimated equal to 0.9959 (Figure 5).

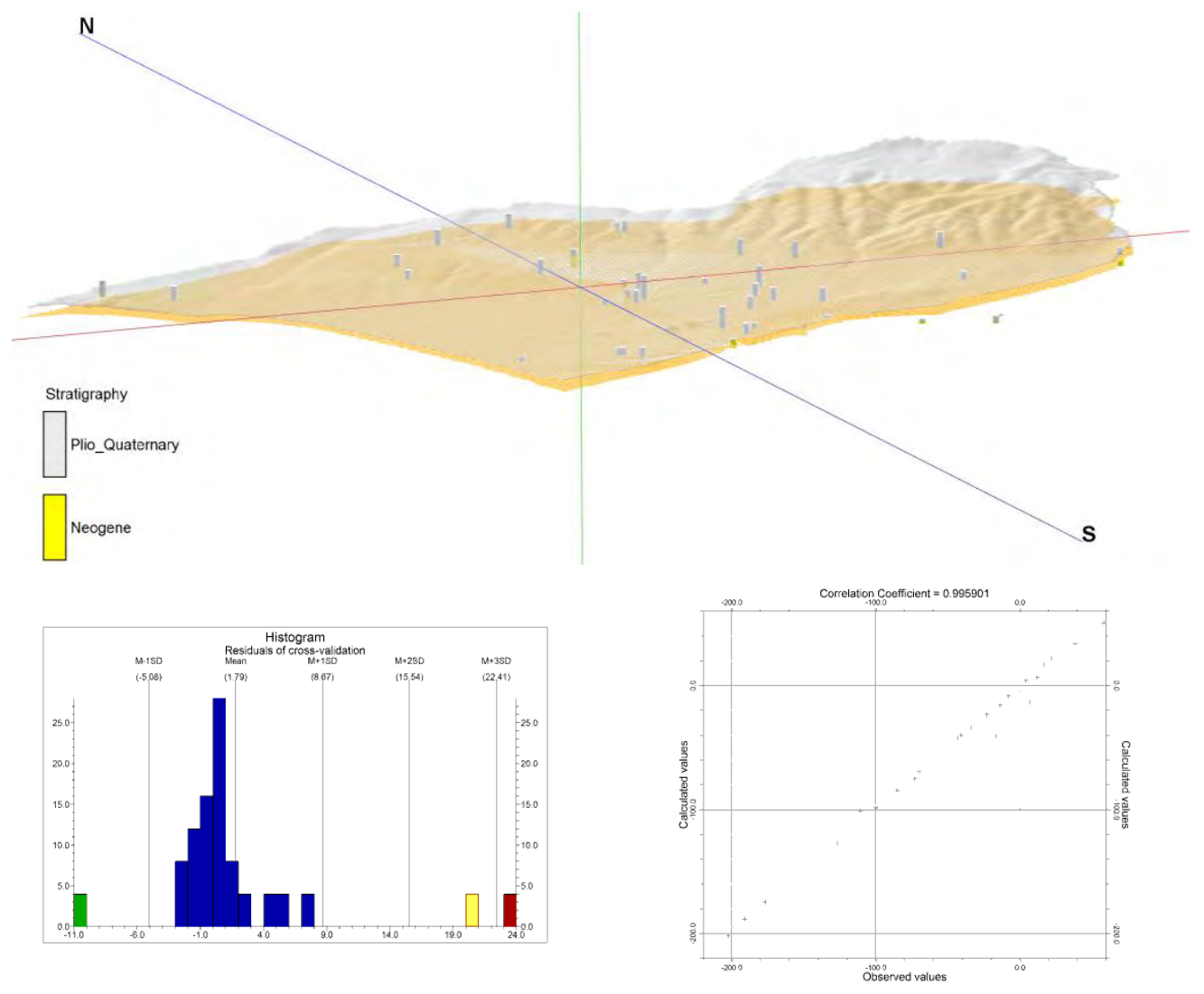

Figure 5 - 3D presentation of the upper Plio-Quaternary surface (transparent surface) and the boundary surface between Plio-Quaternary and Neogene deposits (lower surface). The spatial position of all boreholes is also shown. In the right side are shown the diagrams that resulted from the cross-validation procedure. 
This surface was used as the leading surface to locate areas of any abrupt alteration in the elevation of the stratigraphic contact between Plio-Quaternary and the Neogene Units. Such abrupt alterations are interpreted in the present paper as the result of tectonic activity and for the further identification of possible faults. In order to locate easily the abrupt changes, an isodepth map showing the surface that separates the Plio-Quaternary and Neogene deposits was produced (Figure 6). The construction of the isodepth map can give a general perspective of the changes in the absolute elevation of the upper surface of Neogene formation that occur in the basin (Figure 6). Where abrupt changes occur, the existence of possible faults can be assumed. Based on this concept (Figure 3) several faults were defined. Those faults contributed in the depression or the lift of different parts of the basin (Minus and plus symbols in respect of figure 6).

It should be mentioned that the interpretation of the isodepth map was restricted in the area where enough borehole data are available, so as for the results to be as accurate as possible. Moreover, this interpretation was based on the assumption that the existence of a fault is most probable in sites where the number of the wells increases and the depth-differentiation becomes steeper.

Finally, a rose diagram of the resulting faults was constructed (Figure 7). According to this analysis, two main fault directions predominate in the region, namely NNW-SSE and ENE-WSW.

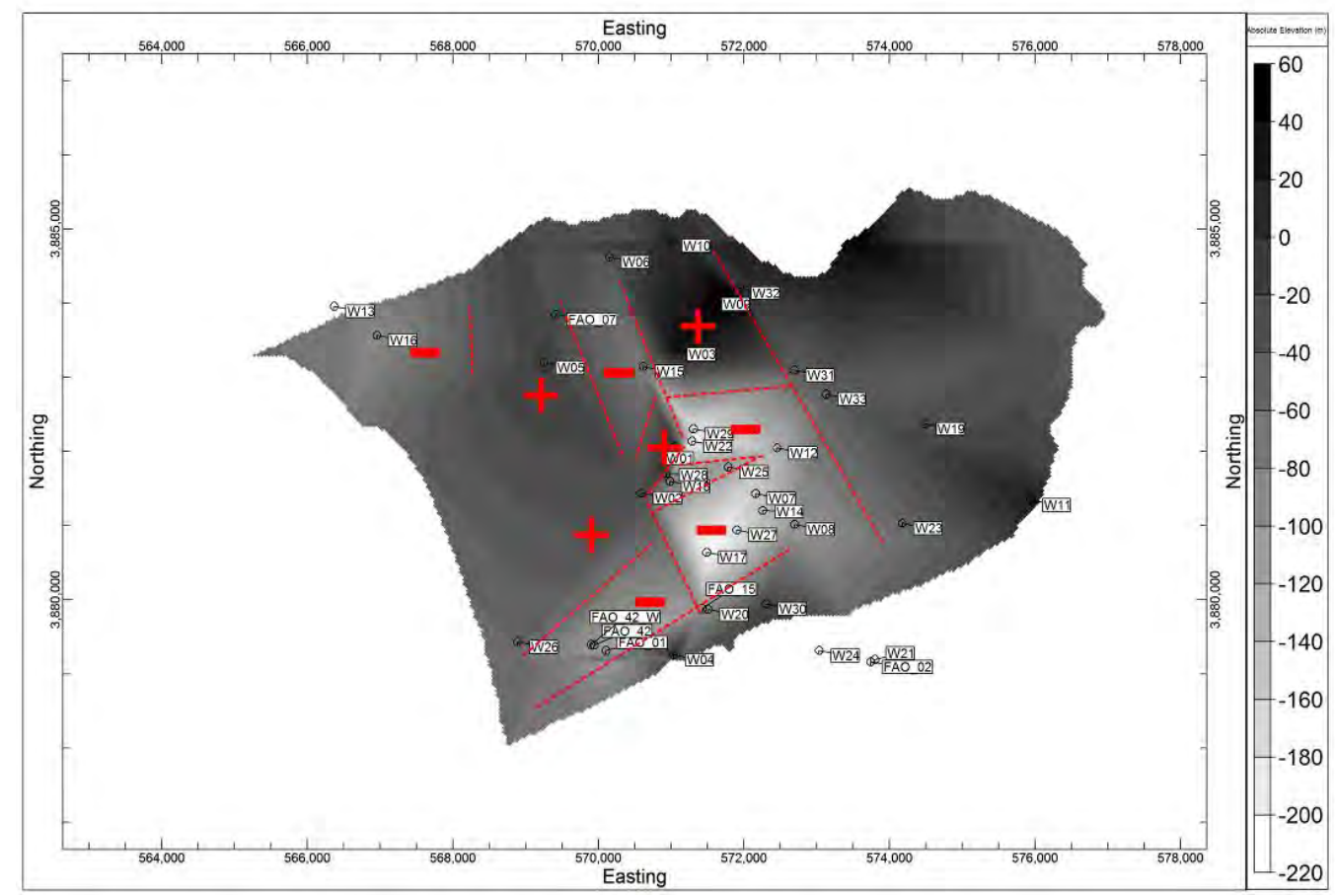

Figure 6 - Isodepth map of the upper surface of Neogene deposits in Tympaki basin. Legend shows absolute elevation in meters. The location of thirty nine (39) boreholes is also shown. Dashed lines depict inferred faults. Plus and minus symbols refer to horsts and grabens respectively.

\section{Conclusions}

In the present work, the litho-stratigraphic study of the area is combined with morphotectonic conclusions of previous study (Peterek \& Schwarze, 2004); and as a result an enhanced concept regarding the tectono-stratigraphical structure of Tympaki basin arises. 


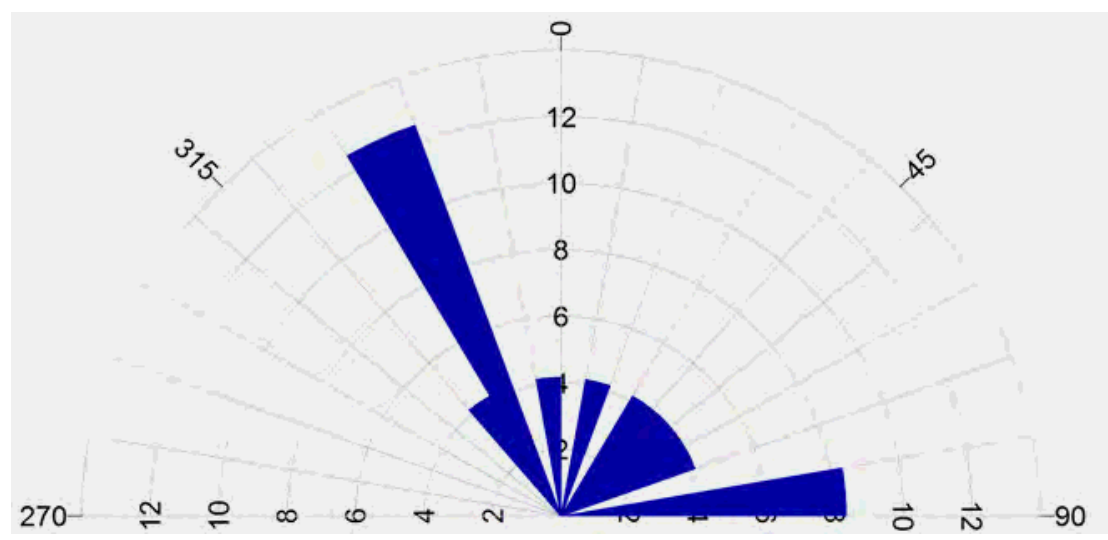

Figure 7 - Rose diagram (percent of total population) of the inferred faults resulted from the interpretation of the isodepth map (Figure 5). Bin size $10^{\circ}$.

The study of the lithostratigraphy, as well as the upper surface of Neogene formation provide strong evidence of faults that are not observed in the surface because the area is covered by recent fluvio-lacustrine deposits.

The analysis of the available data was conducted using an isodepth map of the top surface of the Neogene that resulted from the 3D stratigraphical model, which was constructed using a 3D geological modelling software (RockWorks15, RockWare, Inc.).

Two main fault directions were identified through the analysis. The first one has a general direction NNW-SSE, similar to the strike direction that previous studies have proposed (FAO, 1972; Peterek \& Schwarze, 2004; Paritsis, 2005). The second one has a general direction from ENE to WSW direction, and it follows the strike direction of the faults that bound Tympaki basin in the Northern and Southern limit.

In other words, the drilling data lead to conclusions that are consistent with previous studies regarding the NNW-SSE strike direction; additionally, they underline the existence of a second one pronounced fault with strike direction ENE-WSW that has not been taken into account in previous underground water modelling studies. The latter direction could favour seawater intrusions because exhibit a more or less perpendicular to the coastline position.

The possibility of parallel activation of the two fault sets should make us to consider a more complicated fault-block structure of Tympaki basin that is characterized by a horst-graben structure and the simultaneous activity of crossing normal faults.

In the area where the number of the boreholes is adequate, the isodepth map defines accurately the horst and graben structure (Figure 6). However, where data were sparse the results are questionable and they should be checked by further drilling or geophysical investigation. According to the results, the top surface of the Neogene deposits has been raised in the central area of the basin, representing a horst structure. Such a conclusion should be checked with geophysical investigation up to depth of about 60 to $80 \mathrm{~m}$. Nevertheless, based on the available data it seems quite reasonable to reconsider the tectonostratigraphic structure of Tympaki basin and to investigate the seawater intrusion using advanced research techniques.

\section{Acknowledgments}

This study is part of the work that Technical University of Crete undertakes within the Work Package 1 of the BLACK SEA ERA.NET project, focusing in pollution from sea water intrusion at coastal areas (Tympaki basin). 


\section{References}

Bonneau M. 1984. Correlation of the Hellenide nappes in the south-east Aegean and their tectonic reconstruction. In: DIXON, J. E. \& ROBERTSON, A. H. F. (eds) The Geological Evolution of the Eastern Mediterranean, Geological Society of London, Special Publications, 17, 517-527.

Bonneau M., Jonkers H.A. and Meulenkamp J.E. 1984. Geological map of Greece (1:50.000). Timbakion sheet, I.G.M.E., Athens.

Bonneau M. 1985. Geological map of Greece, 1:50.000, Melambes sheet, I.G.M.E., Athens.

Chatzaras V., Xypolias P. and Doutsos T. 2006. Exhumation of high-pressure rocks under continuous compression: a working hypothesis for the southern Hellenides (central Crete, Greece), Geological Magazine, 143, 859-877.

Fallara F., Legault M. and Rabeau O. 2006. 3-D integrated geological modeling in the Abitidi Subprovince (Quebec, Canada): Techniques and Applications, Exploration and Mining Geology, 15, 1-2, 27-41.

FAO 1972 Study of the water resources and their exploitation for irrigation in eastern Crete Greece. Drillings and pumping tests in Messara AGL:SF/GRE 17/31, Tech. Rep., 26, UNDP, Iraklio.

FAO 1969. Greece: geophysical survey performed in Messara plain (Eastern Crete), Final report, Fondazione Ing. C. M. Lerici Del Politecnico, Milan, Italy.

Jolivet L., Goffe B., Monie P., Truffert-Luxey C., Patriat M. and Bonneau M. 1996. Miocene detachment in Crete and exhumation $\mathrm{P}-\mathrm{T}-\mathrm{t}$ paths of high-pressure metamorphic rocks, Tectonics, 15, 1129-1153.

Kaufmann O. and Martin T. 2008. 3D geological modeling from boreholes, cross-sections and geological maps, application over former natural gas storages in coal mines, Computer \& Geosciences, 34, 278-290.

Kilias A.A., Tranos M. N., Oroxco M., Alonsochaves F.M. and Soto J.I. 2002. Extensional collapse of the Hellenides: a review, Revista de la Sociedad Geological de Espania, 15, 129139.

Kilias A., Fassoulas C. and Mountrakis D. 1994. Tertiary extension of continental crust and uplift of Psiloritis metamorphic core complex in the central part of the Hellenic Arc (Crete Greece), Geol. Rundschau, 83, 417-430.

Klein T., Craddock J. P. and Zulauf G. 2012. Constraints on the geodynamical evolution of Crete: insights from illite crystallinity, Raman spectroscopy and calcite twinning above and below the 'Cretan detachment', International Journal of Earth Sciences, 102, 139-182.

Kokinou E., Alves T. and Kamberis E. 2012. Structural decoupling in a convergent forearc setting (southern Crete, Eastern Mediterranean), Geological Society of America Bulletin, 124, 1352-1364.

Lister G.S., Banga G. and Feenstra A. 1984. Metamorphic core complexes of cordilleran type in the Cyclades, Aegean Sea, Greece, Geology, 12, 221-225.

Meulenkamp J. E. 1979. Field Guide to the Neogene of Crete. In: Symeonidis, N., Papanikolaou, D., Dermitzakis M. (Eds.), Field Guide to the Neogene of Crete, Publ. Dept. Geol. Paleont. Univ. Athens, Series A, 32, 1-32.

Mountrakis D., Tranos M., Papazachos C., Thomaidou E., Karagianni E. and Vamvakaris D. 2006. Neotectonic and seismological data concerning major active faults, and the stress regimes of Northern Greece. In: Robertson M.N.F. and Mountrakis D. (eds) Tectonic Development of the Eastern Mediterranean Region, Geological Society, London, Special Publications, 260, 649-670.

McClusky S., Balassania S., Barka A., Demir C., Ergintav S., Georgiev I., Gurkan O., Hamburger M., Hurst K., Kahle H., Kastens L., Kekelidze G., King R.W., Kotzev V., Lenk O., Mahmoud S., Mishin A., Nadariya M., Ouzounis A., Paradissis D., Peter Y., Prilepin M., Reilinger R., Sanli I., Seeger H., Taeleb A., Toksoz M. N. and Veis G. 2000. GPS con- 
straints on plate motions and deformation in the Eastern Mediterranean: Implications for plate dynamics, J. Geophys. Res., 105, 5695-5719.

National Casastre \& Mapping Agency S.A., DEM with grid size $5 \mathrm{~m}$ x 5m.

Oral M. B., Reilinger R. E., Toksoz M. N., Kong R. W., Barka A.A., Kinik I. and Kenk O. 1995. Global positioning system offers evidence of plate motions in eastern Mediterranean, EOS, Transactions, American Geophysical Union, 76 (9), 9-11.

Papazachos C.B. 1993. Seismological and GPS evidence for the Aegean-Anatolia interaction, Geophysical Research Letters, 26, 17, 2653-2656.

Paritsis S.N. 2005. Simulation of seawater intrusion into the Tymbaki aquifer, South Central Crete, Greece, Report within MEDIS project, Study implemented on behalf of the Department of Management of Water Resources of the Region of Crete, Heraklion, Crete, Greece.

Peterek A. and Schwarze J. 2004. Architecture and Late Pliocene to recent evolution of outer-arc basins of the Hellenic subduction zone (south-central Crete, Greece), Journal of Geodynamics, 38, 19-55.

Reilinger R.E., McClusky S.C., Oral M.B., King R.W. and Toksoz M.N. 1997. Global Positioning System measurements of present-day crustal movements in the Arabia-Africa-Eurasia plate collision zone, J. Geophys. Res., 102, 9983-9999.

Ring U., Glodny J., Will T. and Thomson S. 2010. The Hellenic Subduction System: HighPressure Metamorphism, Exhumation, Normal Faulting, and Large-Scale Extension, Annual Review of Earth and Planetary Sciences, 38, 45 - 76.

Seidel E., Kreuzer H. and Harre W. 1982. A Late Oligocene/Early Miocene High Pressure Belt in the External Hellenides, Geol. Jb., E 23, 165-206.

Tortorici L., Caputo R., Monaco C. 2010. Late Neogene to Quaternary contractional structures in Crete (Greece), Tectonophysics, 483, 203-213. 